Psalmists in Cramped and Open Spaces

A Cognitive Perspective on the Theology of Psalms

Holst, Søren

Published in:

Scandinavian Journal of the Old Testament

Publication date:

2014

Document version

Early version, also known as pre-print

Citation for published version (APA):

Holst, S. (2014). Psalmists in Cramped and Open Spaces: A Cognitive Perspective on the Theology of Psalms.

Scandinavian Journal of the Old Testament, 28(2), 266-279. 


\title{
Psalmists in Cramped and Open Spaces: A Cognitive Perspective on the Theology of Psalms
}

\author{
Søren Holst \\ Købmagergade 44-46, DK-1150 Copenhagen K \\ Email:sh@teol.ku.dk
}

\begin{abstract}
A number of passages in Psalms employ the figure of speech, or perhaps more precisely, the figure of thought, that when the psalmist is in need or in trouble, he is in a tight place, and his salvation consists in being brought out into the open. The article reviews this motif and makes use of methodological approaches from cognitive linguistics, such as the "Conceptual Metaphor Theory" associated with George Lakoff and Mark Johnson, and the "Conceptual Integration Networks" approach or "Blending Theory" introduced by Gilles Fauconnier and Mark Turner, to analyse in more detail the use of this motif in Psalm 18. In conclusion, it is brought up for consideration whether the "cognitive turn" in Biblical scholarship can be fruitfully utilized for the benefit of the sub-discipline of Old Testament Theology, and whether this might imply a re-evaluation of previously discarded ideas about the interrelatedness of language and thought.
\end{abstract}

Key Words: Psalms, metaphor, cognitive linguistics, Johannes Pedersen, James Barr

\section{Psalmists in tight places}

A metaphorical motif occurs in a number of passages in the Book of Psalms: ${ }^{1}$ The psalmist is, so to speak, "caught in a tight place." In translation into some languages, the concrete physical connotations of this expression may be more or less obscured by convention of phrasing. Thus a Danish Bible translation will be likely to employ the word "trængsel," which (exactly like the cognate German "Drangsal" or "Bedrängnis") does indeed etymologically indicate something narrow or unpleasantly tight, but has, by force of convention, come to be used simply as a rather archaic-sounding synonym

1. It is an honour for me contribute to the celebration of Kirsten, Hans Jørgen and Else, from whom I have learned most of what I know about the Old Testament, received inspiration and stolen ideas, and with whom I have enjoyed fruitful collaboration - not least concerning metaphor-over a period of more than two decades.

(C) 2014 The Editors of the Scandinavian Journal of the Old Testament 
for troubles or sufferings. And in English we will be likely not even to find a vague indication of the etymology in actual Bible translations, although you can, in colloquial English, find yourself in a tight corner or in dire straits.

According to most dictionaries, two verbal roots צר can be distinguished, one with the intransitive sense "to be narrow" or the transitive "to tie up," the other one meaning to treat with hostility. ${ }^{2}$ Consequently, we encounter two nouns צִ: One, with an even more frequent and semantically very closely related parallel צָּרָ, meaning narrowness or (taken in a less literal way) distress, the other meaning an enemy. Evidently, this is where philology starts merging into exegesis, since - seeing that enemies on the one hand and suffering or distress on the other are not concepts which are all that different-it may in several cases be debatable which of the two are in evidence. Still, when in Ps 3,2, the psalmist says "How many are "צָ-How many those who rise up against me," they must be people, whereas when in the Psalm immediately following (Ps 4,2), he describes himself as being "in a tight place," this hardly means that he is inside his enemy.

Starting with exactly this passage, Ps 4,2 , the verse depicts the situation well-known from the individual psalms of lament: The psalmist, in crying for help, at the same time refers to help previously received as proof that Yhwh is to be trusted:

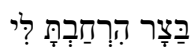

(When I was) in a tight place you made room for me

$$
\text { (Ps 2,4b } \alpha \text { ) }
$$

The spatial connotations of the idea of being that when Yhwh brought the psalmist out of this unpleasant situation, his help took the form of (inelegantly translated) "making wide for me," or "making room for me" (the verb רחב in the hiph'il).

This idea that Yhwh's help consists in "making wide," recurs when Psalm 18,37 , in the context of describing how the psalmist is protected by Yhwh's shield and supported by his right hand, goes on to depict Yhwh's saving action in the following manner:

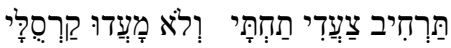

You made my footsteps wide beneath me

(so that) my ankles have not given way.

(Ps 18,37)

When he intervened to rescue the psalmist, Yhwh gave the psalmist room to move freely, so that his ankles would not refuse to carry him.

2. Heinz-Josef Fabry, "צֵ șar I," in Theologisches Wörterbuch zum Alten Testament; Band VI (ed. H.-J. Fabry \& H. Ringgren; Stuttgart a.o.: Kohlhammer, 1989), col. 1113-1122; Helmer Ringgren, "צַ șar II," in Theologisches Wörterbuch zum Alten Testament; Band VI (ed. H.-J. Fabry \& H. Ringgren; Stuttgart a.o.: Kohlhammer, 1989), col. 1122-1126. 
Ps 25,17 supplements צָּרָ with another word for narrow place, the phrase

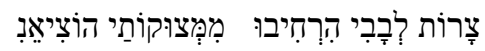

The narrowness of my heart has spread wide;

deliver me from my constraints.

(Ps 25,17)

In the first half of this verse, the idea of a "narrowness," צָּרָ, seems not so much to represent physical restraint to movement, but rather something like the anxiety of claustrophobia, seeing that the psalmist prays to Yhwh concerning the "narrowness of my heart"; some, however, would emend the text to read an imperative, הַרְיב, "make the narrowness of my heart wide,"4 creating a better parallel to the second half of the verse, in which the situation depicted is indeed that of a psalmist in spatially constrained circumstances being "brought out" of his cramped surroundings.

A similarly embodied and internalised conception, so to speak, of the motif of narrow-and-wideness is found in Psalm 31 when the psalmist describes how Yhwh has paid attention to "the narrow circumstances of my nefesh":

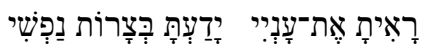

You notice my affliction;

you know the narrow conditions of my nefesh.

(Ps 31,8)

The related term מֵֵצֵ is associated in one Psalm with the realm of the dead:

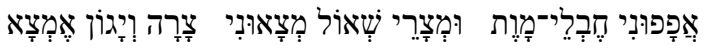

The ropes of death surrounded me;

the narrow places of Sheol got hold of me;

I found narrowness and sorrow.

(Ps 116,3)

Sheol, with its otherwise insatiable appetite, which one might think of as a place of never-ending capacity, is associated here with narrowness. And not only do the etymologically and semantically related terms צִֵַּר accompany each other. They are associated by means of a play on the verb

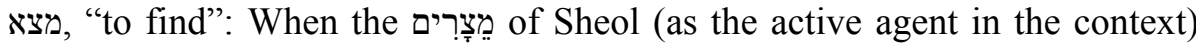
find me, then all that I (passively) find is צָּרָ-a narrow place. Not surprisingly, the outcome, when Yhwh saves the "I" of Ps 116 from the

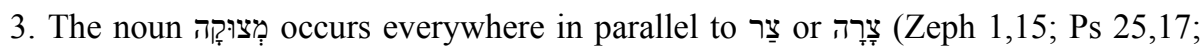

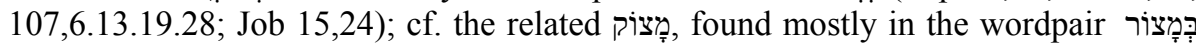

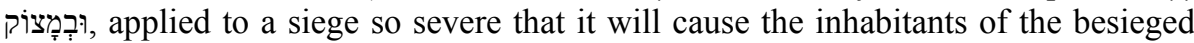
city to turn to cannibalism; the verbal root too, connotes primarily the situation of the besieged city, Deut 28,53.55.57; Isa 29,2.7; Jer 19,9. The motif of being besieged combines the connotations of the two roots צרר, those of enemy activity and spatial constraints respectively.

4. This concept has a parallel in Ps 119,32, which describes the beneficent effects of Yhwh's tôrâ in general by saying "you make my heart wide," תרְחִיב ?ִבְּי 
incapacitating embrace of Sheol, is that the psalmist, as a consequence, is able to walk in verse 9 "in the lands of the living," The lands of the living then, are parallel here to what in Ps 118,5 is more explicitly called "open land." The open land or wide space, מֶרָ is one further building block of the motif cluster of "narrowness-as-problem and wideness-as-solution":

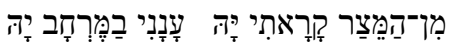

From the tight place I called on $\mathrm{Yh}(\mathrm{wh})$;

$\mathrm{Yh}(\mathrm{wh})$ answered me in the open space.

(Ps 118,5)

It is debatable whether this presupposes that the psalmist has already been brought out into the open by Yhwh and so hears his answer there; or whether it should somehow be implied (or even textually amended) to say that Yhwh's answer consists in bringing the psalmist from a tight corner into open land). ${ }^{5}$

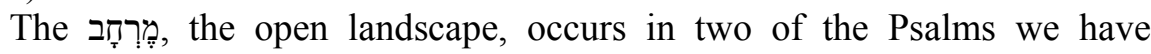
already looked at, thus increasing the suspicion that we are indeed dealing with a terminological cluster that makes up what cognitive linguists would call a conceptual metaphor: In Ps 18, which starts out depicting Yhwh as rock, fortress and shield, and the threat to the psalmist as ropes of Sheol $(18,6$, literally identical to 116,3 that we just looked at), when the psalmist has cried

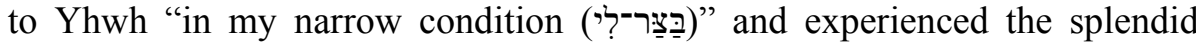
theophany in which Yhwh descends from heaven in a thunderstorm, riding on cherubim, with smoke coming out of his nose, to scatter the psalmist's enemies - we return to the semantic field of cramped and open spaces:

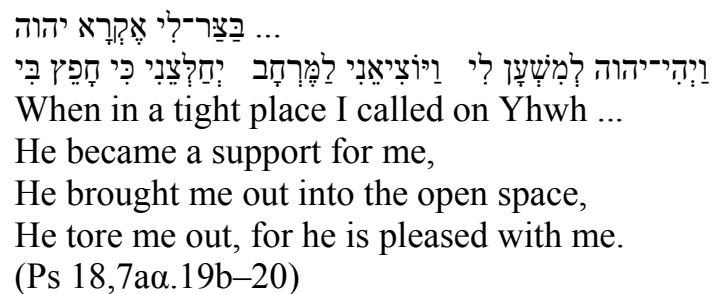

The fire-breathing heavenly warrior Yhwh is transformed into a staff on which the psalmist leans, and Yhwh leads him out ${ }^{6}$ into the open country, the

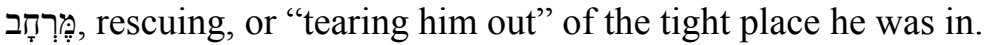

Similarly in Ps 31, immediately following v. 8 in which Yhwh has paid heed to the narrow circumstances of the psalmist's nefesh, the psalmist recounts how Yhwh gave him foothold in the open country:

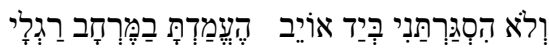

5. Reinhard Feldmeier and Hermann Spieckermann, Der Gott der Lebendigen: Eine biblische Gotteslehre (Topoi Biblischer Theologie, 1; Tübingen: Mohr Siebeck 2011), p. 545; English translation, God of the Living: A Biblical Theology (Waco, Tex.: Baylor University Press 2011), p. 548.

6. The unsurprising 'צiph' $i l$, is parallelled by the more specific nלץ, pi'el, used specifically for "tearing somebody out" of threatening circumstances, not least from Sheol, see Ps 6,5 and 116,8; cf. 34,8; 50,15; 81,8; 91,15 (119,153 ;140,2 with צּ̦רָה $)$. 
You did not close me up in an enemy's hand you let my feet stand in the open space.

(Ps 31,9)

This by no means exhausts the occurrences of this motif, ${ }^{7}$ but it should suffice to demonstrate its widespread use and testify that Bernd Janowski was right in summing up that "it is a characteristic trait of the language of Psalms that being rescued from death is described as an elementary freedom of movement, as "wideness "or "open space "given back to the supplicant in his life-threatening "narrowness "by Yhwh."

\section{Conceptual Metaphor Theory}

Describing one's troubles as "being in a tight place" is evidently metaphorical. It seems to be a metaphor less prevalent in English than in Danish and Biblical Hebrew. And what is true of Danish in this particular detail is probably true of Biblical Hebrew as well: That this metaphor is so well integrated into everyday language that, just as when we call the things that tables stand on, "legs"-we don't even notice employing a metaphor.

It used to be standard practice to call such figures of speech "dead metaphors." "It turns out, however, that in the eyes of recent metaphor theory, "dead" metaphors are in fact the ones which are very most alive.

As long as we regard the fanciful, literary or somehow "special" metaphor as the most interesting one, we are to a certain extent assuming that metaphors are an "extra." We may emphasise the fact that a metaphor is not reducible to abstract speech, that metaphorical speech enables us to express things that could not be said in clinical language, et cetera - but we are none the less implying, that metaphor is "language in overdrive," and tacitly assuming that everyday humdrum language gets by without it.

Conceptual metaphor theory, made famous most of all by George Lakoff and Mark Johnsons "book Metaphors We Live By, claims, quite to the contrary, that metaphor is not one out of several ways in which we may express what we think. Rather, metaphor is the way we think, and we possess

7. Especially, צִ צָר is frequent, and although in many cases no explicit use is made of its possible spatial connotations, see e.g. Ps 46,2 where the powers of chaos encircle those who are in צִ דָָָ 138,7, and 142,3 which describe it in contradistinction to walking freely and surefootedly, and 143,10-11 in which it represents the opposite of the open country of the plain.

8. Bernd Janowski, “'Du hast meine Füße auf weiten Raum gestellt' (Psalm 31,9): Gott, Mensch und Raum im Alten Testament," in: idem, Die Welt als Schöpfung (Beiträge zur Theologie des Alten Testaments, 4; Neukirchen-Vluyn: Neukirchener Verlag 2008), pp. 3-38 (28): "Es gehört zu den Charakteristika der Psalmenprache, $\mathrm{da} ß$ diese Errettung vom Tod als elementare Bewegungsfreiheit, als 'Weite' bzw. 'weiter Raum' beschrieben wird, die dem Beter in seiner lebensbedrohlichen ,Enge' von JHWH zurückgegeben wurde."

9. See, e.g. Kirsten Nielsen, There is Hope for a Tree (JSOTSS, 65; Sheffield: JSOT Press 1989), pp. 51-53, who focuses on the built-in capacity of "dead" metaphors to be brought back to active life. 
no other way. Thinking new thoughts consists in thinking "one thing in terms of another," that is, thinking metaphorically. The most interesting thing about metaphor, therefore, is not that it points out similarities in an illustrative and thought-provoking way, but rather that it creates similarity, and in so doing creates new meaning. ${ }^{10}$

A number of scholars and scientists would suggest that what some call the "cultural big bang" - the rapid appearance of things like tools, representational art and religion among homo sapiens - was due exactly to the apparently more or less simultaneous emergence of language and of the ability to see one thing in terms of another. ${ }^{11}$

Precisely the dead metaphors are evidence that this is our fundamental approach to thinking new thoughts: Our apparatus for thinking is made up of what Lakoff and Johnson call "primary metaphors," such as MORE IS UP, and we are demonstrating this whenever we wish for a "rise "in salary, or say that somebody is "depressed'. ${ }^{12}$

These primary metaphors we combine into entire little systems of metaphorical thought, called "conceptual metaphors"-one of the favourite examples being A PURPOSEFUL LIFE IS A JOURNEY, in which a large number of components may be identified: Thinking of life in terms of a journey, we immediately recognise that a traveller is then a person living his or her life, and an itinerary is a set of long term decisions affecting the course of your life. ${ }^{13}$ As a matter of fact: Just by saying "course of life," I have slipped into using the very metaphor that I was trying to describe from the outside in a cool and detached manner.

"Travelling," in this case, makes up the "source domain," and "life" the "target domain" of the metaphorical utterance. The relation between the elements of the two is described as "mapping." In a similar fashion, then, we might "map" the conceptual metaphor TROUBLE IS LACK OF SPACE in the following manner.

10. George Lakoff and Mark Johnson, Metaphors We Live By (Chicago: The University of Chicago Press 1980), pp. 147-155.

11. Gilles Fauconnier and Mark Turner, The Way We Think: Conceptual Blending and the Mind's Hidden Complexities (New York: Basic Books 2003), pp. 180-187. Merlin Donald, A Mind So Rare (New York: Norton 2001), pp. 259-62 and 274-85. Edward Slingerland, What Science Offers the Humanities: Integrating Body and Culture (Cambridge: Cambridge University Press, 2008), pp. 152-56.

12. George Lakoff and Mark Johnson, Philosophy in the Flesh (New York: Basic Books 1999), pp. 49-59.

13. Edward Slingerland, "Conceptual Metaphor Theory as Methodology for Comparative Religion," Journal of the American Academy of Religion 72/2 (2004), pp. 1-31 (8-13), DOI: 10.1093/jaarel//fh002 


\begin{tabular}{|lll|}
\hline Source domain & \multicolumn{2}{c|}{ Target domain } \\
lack of space & $\rightarrow$ & trouble \\
particular tight place & $\rightarrow$ & suffering from X \\
person in tight corner & $\rightarrow$ & psalmist \\
getting out & $\rightarrow$ & divine intervention \\
open space & $\rightarrow$ & good life \\
\hline
\end{tabular}

\section{Conceptual Integration Networks ("Blending Theory")}

This model for explaining what happens in the metaphor works fine when the mapping is, so to speak, unilateral: When saying "the Lord is my shepherd," the psalmist maps what we know about shepherds unto the domain of his relationship to God. But what actually happens in metaphorical speech may be more complicated - and possibly always is so. The most important further development of this theoretical approach has been done to take account of what happens when we do not just understand the target domain better by understanding it "in terms of" the source domain, but rather both domains (or "mental spaces" as they are called within this school of thought) contribute to a resulting third space (the "blend" or "the conceptual integration" of the two) which is something entirely novel. ${ }^{14}$ Figure 1 above has become the standard representation of such a relationship: The generic space represents that which the two input spaces are seen as having in common, and which makes the blending of them relevant or even possible in the first place (like "relationship" or "caring" in the "Lord-as-shepherd" metaphor). The two input spaces are equivalent to the "source" and "target" domain of the Lakoff/ Johnson model. The novel aspect of the model is the "blend" (or "blended space"), representing the fact that the blending of the two input spaces results in something genuinely new that is not satisfactorily described by saying that "source" is mapped onto "target," since the blend is not directly equivalent in structure to either of the individual input domains.

14. The foundational text for this theoretical approach is Gilles Fauconnier and Mark Turner, "Conceptual Integration Networks," Cognitive Science 22 (1998), pp. 133187; an updated edition is available online at http://papers.ssrn.com/sol3/ papers.cfm?abstract_id=1292966 [accessed 9 April 2014]. Two of several useful introductions can be found in Pierre J.P. van Hecke, "Conceptual Blending: A Recent Approach to Metaphor. Illustrated with the Pastoral Metaphor in Hos 4,16," in Metaphor in the Hebrew Bible (ed. P. Van Hecke; Bibliotheca Ephemeridum Theologicarum Lovaiensium, 187; Leuven a.o.: Peeters, 2005), pp. 215-231 (218223); Slingerland, What Science Offers, pp. 174-88. 


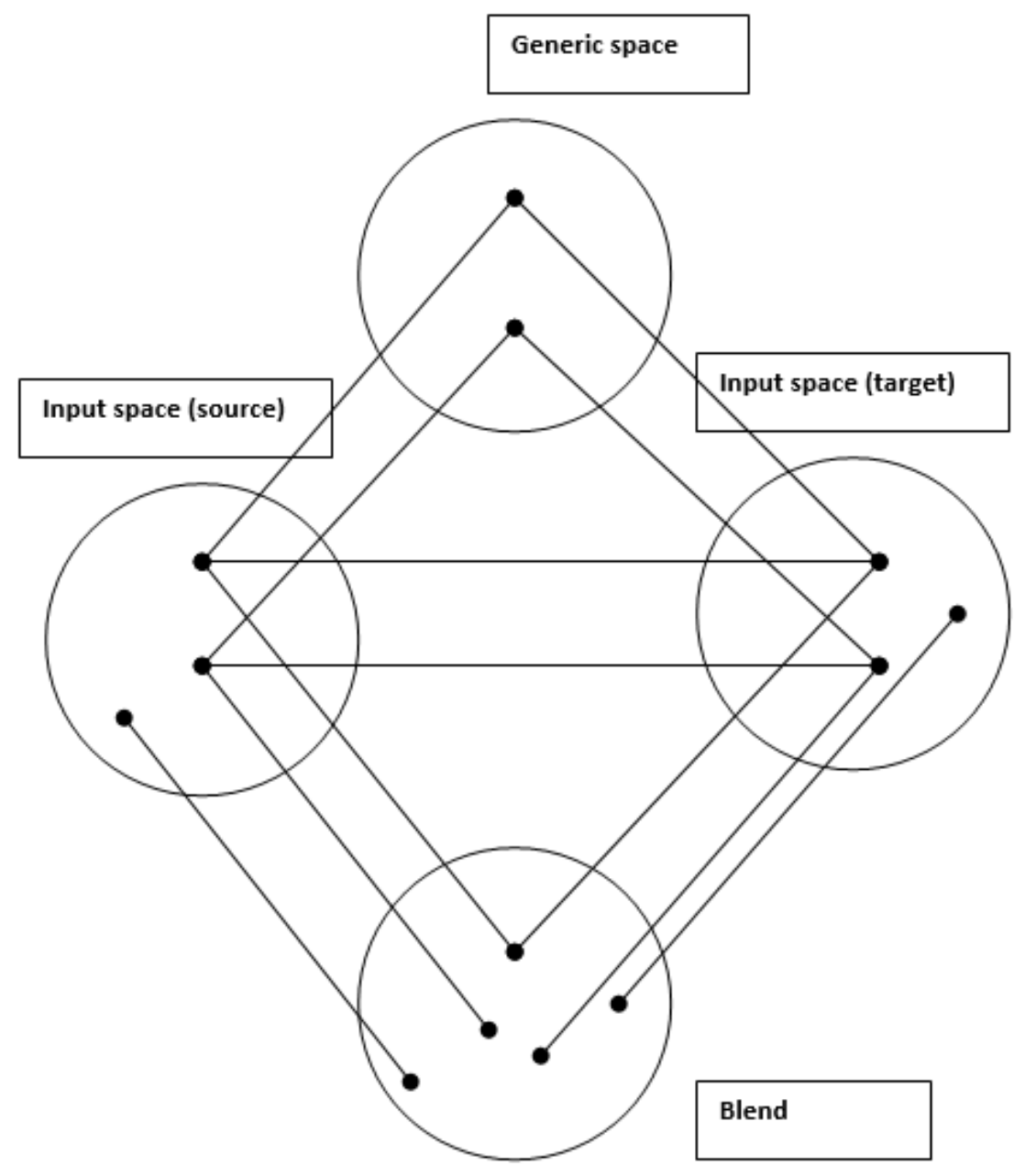

Figure 1

This model has two advantages over the simpler one presented above. First, it allows room for what used to be called the "interaction theory" of metaphor: That both "Sachteil" and "Bildteil" (or tenor and vehicle) of the metaphor contribute to the meaning created. ${ }^{15}$ Saying "the lord is my shepherd" not only adds new meaning to the way you think about God, but to the way you think about shepherds as well. And second, the model is conveniently applicable to cases where more than two "mental spaces" are involved. I will try to demonstrate this, using Psalm 18 as the exercise field.

15. Nielsen, There is Hope, pp. 48-56; Göran Eidevall, Grapes in the Desert: Metaphors, Models, and Themes in Hosea 4-14 (ConBOT, 43; Stockholm: Almqvist \& Wiksell International, 1996), pp. 20-24. 


\section{Narrowness, water and death}

Psalm 18 lets several different motifs crop up, and - not least-blend together in the course of the Psalm. Thus it provides us with an opportunity to demonstrate the capacity of blending theory to account for the creation of meaning "on the fly," when a complex system is constructed as several mental spaces contribute to new "blends "over the course of a textual discourse. ${ }^{16}$ Beginning with just the double parallelism of v. 5-6, the forces that threaten the psalmist are described in the form of an intricate pattern of terms that neatly follow the expected behaviour of Hebrew poetic parallelism, while also in at least one case stretching the habitual boundaries of such a construction rather seriously:

\begin{tabular}{|c|c|}
\hline 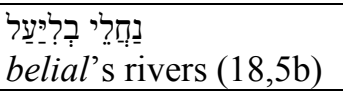 & 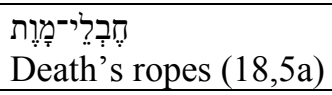 \\
\hline 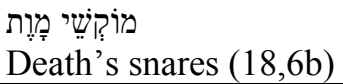 & $\begin{array}{l}\text { חֶבְלִי שְׁאוֹל } \\
\text { Sheol's ropes }(18,6 a)\end{array}$ \\
\hline
\end{tabular}

Sheol in v. 6a forms a parallel construction with "death," מוֹ both in 5a and $6 \mathrm{~b}$. The corresponding slot in verse $5 \mathrm{~b}$ is taken up by Belial. Exactly the present passage is often quoted in support of seeing Belial as some sort of sinister power of the underworld or the forces hostile to the plans of God. ${ }^{17}$ This would give us a nice chiasm, with Sheol and Belial forming a pair; the fact remains, nonetheless, that in almost all cases in the Old Testament, Belial merely means worthlessness or evil, often in a legal sense. ${ }^{18}$

Thus, the forces of death and destruction are expressed by the identical "death" in 5a and 6b with a synonymous parallel, Sheol, in 6a, and Belial in $5 \mathrm{~b}$ forming a possibly more doubtful synonym or parallel. For the element occurring in construct to these powers of death, there is complete identity between $5 \mathrm{a}$ and $6 \mathrm{a}$, "ropes," and a parallel in $6 \mathrm{~b}$ in the form of "snares" or other sorts of traps. The combination of intricately interweaving elements of parallelism is certainly well crafted. It almost makes you expect $5 \mathrm{~b}$ to behave itself and fit into the pattern; which, indeed I do think that it does, but with a difference. For ropes and snares in the other three slots, $5 \mathrm{~b}$ substitutes rivers, which may certainly be things to be afraid of in Psalms (although mostly they are not even that), but are usually not thought of as things that tie you up.

If we present the relation of these images to each other in the form of a conceptual blend analysis, we get something like the following figure. To simplify the graphic representation, I have let the circles be simple rectangles, and left out the top element, the "generic space" of the conceptual blend figure:

16. Slingerland, What Science Offers, p. 188

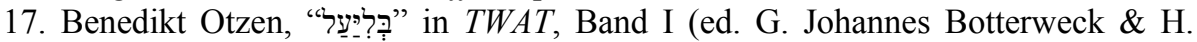
Ringgren; Stuttgart a.o.: Kohlhammer, 1973), col. 654-658 (656).

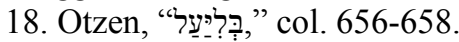




\begin{tabular}{|c|c|}
\hline $\begin{array}{l}\text { Agent: Death/Sheol } \\
\text { Act: binding } \\
\text { Means: rope/snare } \\
(5 a, 6 a-b)\end{array}$ & $\begin{array}{l}\text { Agent: Beli'al, worthlessness, } \\
\text { nothingness } \\
\text { Act: terrifying (= drowning?) } \\
\text { Means: rivers } \\
\text { (5b) }\end{array}$ \\
\hline \multicolumn{2}{|c|}{$\begin{array}{l}\text { Death/Sheol as worthlessness/nothingness } \\
\text { Rivers as ropes } \\
\text { Fear of drowning = claustrophobia of being tied up } \\
\text { (being immobilised) }\end{array}$} \\
\hline
\end{tabular}

As in the more elaborate model above, we have two input domains, and below them, the blend resulting from seeing these domains in terms of one another. V. 5-6 blend two ideas of the psalmists plight: On the one hand, Death and Sheol are binding, surrounding or trapping him, using ropes or snares (which is to say: ropes employed for a specific purpose), and the central issue of this input domain would seem to be either that in death one ends up being immobile - or that in dying one is made a prisoner, incarcerated, locked up, in the location associated with death, namely Sheol). In input domain no. two, the psalmist is being threatened or frightened by

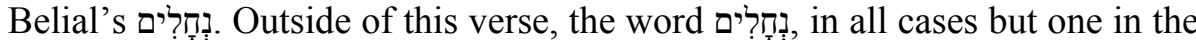
Psalms, describes rivers as something that has entirely positive connotations, associated as they are with Yhwh's well-thought-out ordering of his world and with watering the land to make it fertile. Only in Ps 124 are these rivers representative of the waters of chaos which, but for the help of Yhwh, would have swallowed up Israel. In the present passage of Psalm 18, then, either "rivers of destruction" or simply "evil, worthless, despicable rivers" occur in tandem with the immobilising ropes of Death and the underworld.

The blend created implies a concept in which rivers are ropes, which not only drown, but tie down the person submerged in them, and the force tying the knots, so to speak, is Belial, wickedness or worthlessness, which is equal to Death or Sheol. And since the verb describing the activity of the rivers of Belial is terrify, בעת, it is tempting to associate the effect of this immobilising threat with claustrophobia.

Now, I wanted to start with v. 5-6, because here we seemingly have two input domains combining to form a blended domain within a single distichan obvious case of two spaces mapped unto each other. This blend, however, is really in itself the second link in a course of blending processes that begins in v. 1 and is taken up in v. 4. The psalm superscription identifies the psalm as being the words that David spoke to the lord on being rescued from the

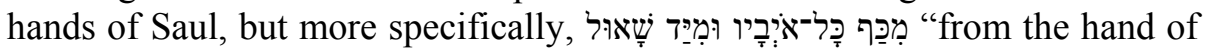
all his enemies and from Saul"-and even if we exercise the customary restrained attitude to the superscriptions, the enemies are there by implication in v. 3, which not only heaps up metaphorical descriptions of Yhwh as rock,

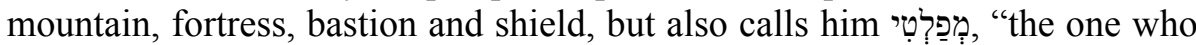


lets me escape," and in v. 4 their presence is quite explicit: "I cry to the Lord and

On top of this, then, comes the passage we just looked at, which introduces the powers of Death, Sheol and Belial as further descriptions of that which troubles the psalmist, with no indication whatsoever that a new subject is being introduced. In other words, it hardly makes sense to think that troublesome neighbours on the one hand and subterranean powers of chaos on the other are-independently of each other-giving the psalmist a hard time, or that different episodes succeed each other. The subject matter is one and the same, namely the present situation of the psalmist (and this, I think holds good for the entire psalm).

\begin{tabular}{|l|l|}
\hline $\begin{array}{l}\text { Agent: Death/Sheol as Beli'al } \\
\text { Act: immobilising by means } \\
\text { of ropes/rivers }\end{array}$ & $\begin{array}{l}\text { Agent: Human enem } \\
\text { Act: pursuing }\end{array}$ \\
\hline $\begin{array}{l}\text { Enemies are forces of Death/sheol/nothingness } \\
\text { (or Death is a pursuing enemy) }\end{array}$ \\
$\begin{array}{l}\text { Fleeing from enemies = immobilisation by ropes of Death } \\
\text { (which is also destructive waters } \approx \text { drowning) }\end{array}$
\end{tabular}

In this blend, then, we have one input space containing the situation analysed in v. 5-6, and another input space consisting of the hostile activity of human enemies of the psalmist. Together they form a blend in which hostile neighbours are seen as powers of Death and the underworld and its ropes, snares and rivers: They not only pursue you physically or economically, they bind you up with ropes that impose a deathlike immobility on you and make you feel that rivers of ill-omened waters wash over you.

Putting it this way, though, assumes, that what we have is a simple-scope blend, in which the input space of death, ropes and water is unequivocally the source domain and human enemies the target domain. We then map the conceptual structure of the former unto the latter-the two being, in more traditional parlance of metaphor theory, Bildteil and Sachteil or vehicle and tenor respectively. ${ }^{19}$

19. It is possible to depict metaphorically one's enemies as being identical to death itself; something very like this is presumably what is happening in Ps 124,1-3, where Israel rejoices in the help received from Yhwh, which averted the threatening prospect of being swallowed alive by human opponents, frequently swallows people alive in the Bible is "the deep" (מְצוּלָה, Ps 69,16) or the ground itself beneath which Sheol is located (cf. Num 16,30-34; 26,10; Deut 11,6; Ps 106,17). The opposite process, or perhaps more correctly: The opposite or complementary effect of the very same "mapping" of the semantic domains of enemies and Death unto each other, could result in describing Death as an enemy; this, as far as I can find, is not obviously present in the Hebrew Bible, but is certainly found in the New Testament (1 Cor 15,26). 
This seems eminently sensible: The psalmist is persecuted by enemies and describes them as powers of death. If we were trying to locate the real-world referent of the text, we would probably cast our vote for this interpretation. But if we are rather trying to find out what goes on in the text, it is equally possible to find in it a characterisation of the powers of Death as pursuing enemies: Death not only lies in wait, setting traps, preparing to surround its victim and let its terrifying waters flow over him-it even runs after him, pursuing him in the actual land of the living, where Death and Sheol ought not to belong, but where (as other individual psalms of lament testify) they are none the less sometimes encountered. Such a double-scope blend would tell us not only how the psalmist perceives his enemies and in what artfully strong language he depicts them, but would also add dimensions to our understanding of the way he views Death and the underworld.

Having characterised the content of v. 1-6 in this way, we note that the following section, vv 7-16, in which Yhwh comes to the psalmist's rescue, is

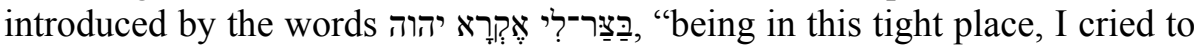
Yhwh."

This gives us occasion for yet another blending chart, illustrating how the fact that here the situation described up to this point is summed up as being in a tight place, creates a new blend of meaning:

\begin{tabular}{|c|c|}
\hline 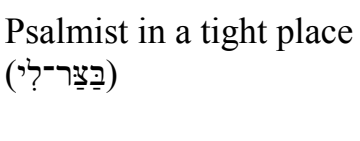 & $\begin{array}{l}\text { Bound with ropes of Death }= \\
\text { Threathened by rivers of Belial = } \\
\text { Pursued by enemies }\end{array}$ \\
\hline \multicolumn{2}{|c|}{$\begin{array}{l}\text { Suffering death, chaos and persecution is being in a tight place, having } \\
\text { movement restrained }\end{array}$} \\
\hline
\end{tabular}

The entire incapacitating and life-threatening experience that the palmist suffers at the hands of the powers hostile to his life-be they death, water or enemies or a combination of the three-is summed up here as being in a tight place without room to move.

Skipping over the tremendous theophany in vv 8-16, where a firebreathing Yhwh swoops down from heaven, we jump now to vv 17-20 where we find the beginning of the solution to the problem set out in vv 1-6 (or 1-7) in terms that constitute pretty much the positive mirror image of what we have looked at until now: 


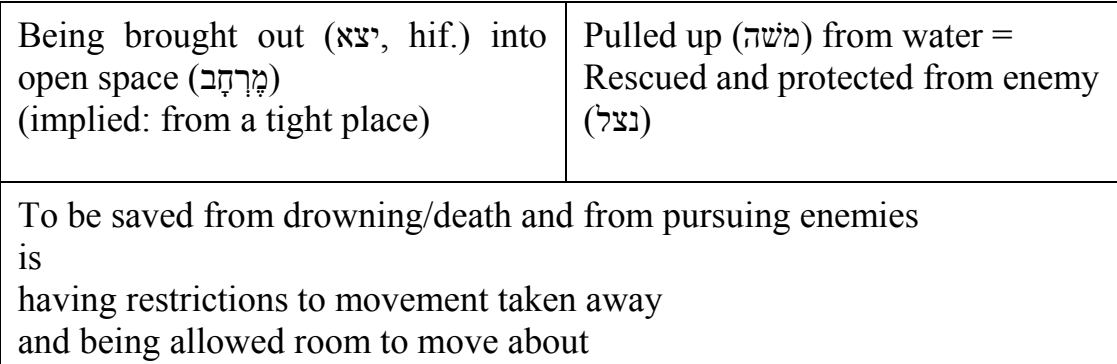

Being pulled up out of the waters and/or rescued from pursuing enemies is tantamount to suddenly being allowed freedom to move in the מֶרִ -in open land.

\section{Contribution to the Theology of the Old Testament?}

Does all this serve any purpose within the discipline of Old Testament Theology? Looking through my bookcase, one of the few places in which I found a mention of the passages discussed here was Johannes Pedersen's Israel, in which he describes the psalmist's experience of not having room to move as an aspect of Sheol reaching into the land of the living, and associates this with the specific nature of "Israelitic thought." 20

Pedersen, of course, is a classic, but hardly a present-day scholarly authority. On the contrary, in some ways he represents things that we know we should abstain from doing to the biblical text. When teaching a class, I repeatedly catch myself saying things like "this reflects a general world view in the Old Testament according to which ...," and I keep saying these things because they seem to be the most convenient way of describing certain aspects of what I actually think are demonstrably found in the texts. At the same time, however, I feel slightly guilty about it, being fully aware that a too heavy-handed use of such an idea as "the biblical world view" or "the biblical way of thinking" borders on a "Pedersenian" mode of speaking, the inadmissibility of which has long since been demonstrated by people like James Barr.

Barr famously took Pedersen and a whole related school of thought apart: ${ }^{21}$ attempts to demonstrate a correlation between thought and language, especially in branches of scholarship related to theology, have been suspect ever since. And certainly the romantic idea of a specific Hebraic "Geist" being built into the structure of the Hebrew language is not a thing we should try to resurrect, but cognitive linguistics seems to demonstrate that the use made of language is indeed to a certain extent an expression of a specific

20. Johannes Pedersen, Israel: Its Life and Culture (London: Oxford University Press), p. 149; 527 (note to p. 330). For Pedersen's view of the interrelatedness of Hebrew language and "Israelitic thought," see e.g. p. 123.

21. James Barr, The Semantics of Biblical Language (Oxford: OUP, 1961), see e.g. the discussion of "root meanings" in Biblical Hebrew, pp. 100-106. 
world view which belongs to more than just the level of the individual speaker or writer of the individual text. ${ }^{22}$

Recent explorations of this idea include the work of scholars such as Job Jindo and Enio Mueller. ${ }^{23}$ Mueller indicates - and scholars like Slingerland would agree - that while Pedersen was demonstrably wrong to anchor his "Israelitic manner of thinking" in the collective spirit of the Hebrew nation, Barr, too, in trying to abstract the meaning of language from its context was not altogether on the right track. Cognitive science indicates that cognitionand as a result its expression in language - is first and foremost embodied. ${ }^{24}$ Being grounded in the body, it is primarily "universal" in the sense that speaking of a specifically Hebraic way of thinking contrasted with a Greek one is out of the question; that being said, seeing cognition as grounded in the body leaves room for investigating to what specific use language is being put in a specific cultural context, and to what extent cognition and its expression in language take on culture-specific forms. ${ }^{25}$ Possibly, therefore, it might make sense to go back and re-read Pedersen and see which of his observations of what goes on in the Biblical text may still be of interest, in spite of the fact that the reasons he would give for e.g. the psalmists "experience of being in a tight place will no longer hold.

22. Slingerland, What Science Offers, pp. 206-218.

23. Job Y. Jindo, "Towards a Poetics of the Biblical Mind: Language, Culture and Cognition," VT 59 (2009), pp. 222-243, DOI: 10.1163/156853309X406659

Enio R. Mueller, "The Semantics of Biblical Hebrew: Some Remarks from a Cognitive Perspective," 18 p. [accessed 1 April 2014]. Online:

www.sdbh.org/documentation/EnioRMueller_SemanticsBiblicalHebrew.pdf.

24. Mueller, "Semantics," pp. 6-11.

25. Jindo, "Towards a Poetics," pp. 224; 229-231. 